
THE PROBLEM OF GEOGRAPHIC BALANCE

\author{
Farley Grubb \\ Working Paper 14267 \\ http://www.nber.org/papers/w14267 \\ NATIONAL BUREAU OF ECONOMIC RESEARCH \\ 1050 Massachusetts Avenue \\ Cambridge, MA 02138 \\ August 2008
}

The author thanks Stephen Douglas and Zachary Rose for research assistance and Tracy McQueen for editorial assistance. The views expressed herein are those of the author(s) and do not necessarily reflect the views of the National Bureau of Economic Research.

NBER working papers are circulated for discussion and comment purposes. They have not been peerreviewed or been subject to the review by the NBER Board of Directors that accompanies official NBER publications.

(C) 2008 by Farley Grubb. All rights reserved. Short sections of text, not to exceed two paragraphs, may be quoted without explicit permission provided that full credit, including $\odot$ notice, is given to the source. 
The Distribution of Congressional Spending During the American Revolution, 1775-1780:

The Problem of Geographic Balance

Farley Grubb

NBER Working Paper No. 14267

August 2008

JEL No. E62,H60,H77,N11,N41

\begin{abstract}
Resources to fight the War for Independence from Great Britain (1775-1783) were to be provided to the U.S. Congress by the individual states based on each state's population share in the united colonies. Congressional spending, however, largely flowed to where the theater of war was located. Thus a geographic imbalance in revenue and spending arose. Because much of the spending was through issuing paper money, geographic variation in inflation as well as in general economic activity resulted. This in turn affected the relative strength of each state's attachment to the union with ramifications on maintaining political unity.
\end{abstract}

Farley Grubb

University of Delaware

Economics Department

Newark, DE 19716

and NBER

grubbf@lerner.udel.edu 


\section{The Distribution of Congressional Spending During the American Revolution, 1775-1780: The Problem of Geographic Balance*}

Resources to fight the War for Independence from Great Britain (1775-1783) were to be provided to the U.S. Congress by the individual states based on each state's population share in the united colonies. Congressional spending, however, largely flowed to where the theater of war was located. Thus a geographic imbalance in revenue and spending arose. Because much of the spending was through issuing paper money, geographic variation in inflation as well as in general economic activity resulted. This in turn affected the relative strength of each state's attachment to the union with ramifications on maintaining political unity.

The united colonies assembled in a Second Continental Congress on 10 May 1775 in

Philadelphia to discuss a common response to the conflict between Massachusetts and the British Crown. The battles of Lexington and Concord had already occurred and the British forces which

had retreated to Boston were now under siege by Massachusetts militia. Resources and men were already on the move from other states to support the Massachusetts revolutionaries. Congress, with no legal authority, decided to make itself the de facto united revolutionary government. Congress' immediate problem was marshaling resources for a united effort against the British occupying Boston. The provision of these resources helped sustain the near year-long siege of, and final expulsion of British forces from, Boston. In the spring of 1775, independence was not yet the dominant sentiment. It would take a full year of open warfare-victory in the battle for Boston, the pending battle for New York, and the campaigns against British Canada — before Congress would declare independence on 4 July 1776 (Tindall 1988, pp. 210-20). It quickly became clear that Congressional marshalling of resources for a united effort against the British was not a one-off exercise but would need to be continued for some time.

As these events unfolded, Congress had to improvise a fiscal policy and do so under extreme wartime duress and questionable political legitimacy. It was an improvised extralegal 
revolutionary body without any constitutional structure of organization. As such, it exercised power by common consent of the states as represented by their delegates in Congress. The Articles of Confederation were not laid before Congress until November of 1777, and they were not ratified by the states until March 1781 (Journals of the Continental Congress [JCC hereafter] vol. 9, pp. 907-28, vol. 19, p. 233; Tindall 1988, pp. 247-48). ${ }^{1}$

As a more-or-less voluntary assembly of states, Congress decided that resources - men, money, and material - required to support the united war effort against the British would be provided by the states to Congress in proportion to each states' economic strength and ability. Congress had no separate power to directly tax the public or the states. Nor did Congress have power to enforce compliance by the states of its requisition requests. Provision of requisitioned resources by the states was basically voluntary. A sense of fairness in resource extraction by Congress was likely needed to maintain political unity under such a voluntary system. By contrast, where these resources would be spent was largely determined by the exigencies of war. As such, an imbalance between where resources were extracted and where they were spentfrom which states they came versus in which states they were accumulated—was likely to occur.

The primary goal of this paper is to describe and quantify this geographic imbalance between Congressional revenue and spending flows over the first five years of the War for Independence (1775-1780) — the years dominated by the emission of Congress' Continental Dollar paper money. Part of this effort entails estimating a breakdown of Congressional spending by source, type, and location for each year as well as establishing the distribution of resource demands requested of each state by Congress.

Much of the spending by Congress during the first five years of the war was in the form of a paper money that Congress had created - the Continental Dollar. This money was structured 
as a zero-interest bearer bond that the states were required to redeem in the near future (Grubb 2008c). A secondary goal of this paper is to estimate what share of Congressional spending took this form and to tally up and evaluate Congress' yearly budgets with respect to deficits and surpluses during the era spanned by the Continental Dollar. This in turn is used to reevaluate the fiscal/monetary course of the war and, in conjunction with the location of spending, to explore the geographic imbalance across the states of these massive monetary injections and the localized price disturbances they may have caused. This form of Congressional resource creating and spending collapsed in 1780, which explains the end year of the current study. Future work will take this analysis through the final years of the war (1781-1783), a period that presents a different and more complicated set of accounting challenges.

State adherence to Congressional resource requests is used to construct an index of state commitment to the union. The geographic imbalance in Congressional revenue requests versus spending flows is then used to explain the variation in this commitment. The extent that confederations and federalism depend on geographic balance in national fiscal/monetary policy, even during wartime emergencies involving patriotic exuberance, and how fragile such unions can be in the face of such imbalances is an important consideration for evaluating the early history of U.S. political survival. This paper explores a different perspective of the American Revolution by focusing on the initial construction of fiscal federalism and the problems it may have created both during the Revolution and into the early Republic. Being exploratory, the hope is that this paper will help stimulate scholarly interest to develop this line of research further.

\section{The Geographic Distribution of Congressional Resource Demands}

In June of 1775 , one month after convening, Congress had committed itself to a united military effort against the British in Boston. It had to raise substantial sums of money to finance 
this effort, namely to pay monthly wages to soldiers, provision them, and provide military arms for the Continental army as well as to meet sundry expenses that accompany a functioning central government. It could not directly tax the public or the states, and it had no resources or assets of it own. The states were not in a position to immediately deliver money to Congress. Thus, Congress had to borrow. As a government with questionable legitimacy, it could not easily borrow from foreigners or even directly from its own people. Thus, it resolved to borrow from itself, namely from its constituent states, as a united entity rather than merely sanction separate state borrowings with some sort of national endorsement (Grubb 2008c).

Congress accomplished this borrowing by issuing zero-interest bearer bonds, called Continental Dollars, which the states as assembled in Congress pledged to redeem and return to the Congressional treasury to be burned. Congress initially authorized $\$ 2$ million on 22 June 1775 with another million authorized on 25 July 1775 . The redemption value in specie was printed on the face of each Continental Dollar and the redemption or maturity date was set by legislation. The states were not required to start redeeming these bearer bonds until December 1779 nor finish redeeming them before December 1782. Future emissions would not have to be redeemed until as late as 1797. Congress also asked the states to make Continental Dollars a legal tender within their respective states in order to force acceptance of them as Congressional agents spent them to acquire resources and pay soldiers—a request to which states complied (Grubb 2007, 2008a, 2008b, 2008c; JCC vol. 2, pp. 221-23, vol. 3, p. 458, vol. 13, p. 64; Newman 1997, pp. 33-35, 59-68).

In this initial action Congress also established how the states would contribute resources to Congress, in this case what share of the total Continental Dollars issued by Congress each state would be required to redeem. The resolution stated: 
That each colony provide ways and means to sink its proportion of the bills [Continental Dollars] ordered to be emitted by this Congress, in such manner as may be most effectual and best adapted to the conditions, circumstances, and usual mode of levying taxes in such colony.

That the proportion or quota of each colony be determined according to the number of Inhabitants of all ages, including negroes and mulattoes in each colony; But as this cannot, at present, be ascertained, that the quotes of the several colonies be settled for the present, as follows, to undergo a revision and correction, when the list of each colony is obtained (JCC vol. 2, p. 221).

The percentage contributions are listed in Table 1, column 2. Georgia was not yet in Congress and so received no quota. The basic idea was that the total resources needed for the united war effort as executed by Congress would be supplied by the states in proportion to each state's relative economic strength and ability. How to assess that relative economic strength was not obvious or easy to accurately estimate. The initial choice was by relative population shares in the union, in part because it was highly correlated with economic strength and ability to deliver resources, but mostly because it was an easy-to-measure expedient. Even relative population shares, as indicated in the resolution quoted above, were not known with exact certainty.

[Place Table 1 Here]

Congress adopted the Articles of Confederation 15 November 1777. Article 8 of the Articles stated that:

All charges of war and all other expenses, that shall be incurred for the common defence or general welfare, and allowed by the United States, in Congress assembled, shall be defrayed out of a common treasury, which shall be supplied by the several states, in proportion to the value of all land within each State, granted to or surveyed for any person, as such land and the buildings and improvements thereon shall be estimated according to such mode as the United States, in Congress assembled, shall, from time to time, direct and appoint.

The taxes for paying that proportion shall be laid and levied by the authority and direction of the legislatures of the several states, within the time agreed upon by the United States, in Congress assembled (JCC vol. 9, pp. 913-14).

Thus, by mid-November 1777 relative land value including the improvements made on the land across the states was established as the criterion for determining what share of total resources 
demanded by Congress each state would be required to provide. While the Articles would not be ratified by the states until March 1781, its ratification basically legitimized the status quo in that from 15 November 1777 Congress operated under its auspices (Tindall 1988, p. 248). However, it is unclear whether the relative land-value criterion for apportioning resources to be supplied to Congress from among the states was ever implemented. The lack of accurate information on relative land values including improvements made on the land and the difficulty of obtaining such information under wartime circumstances may have made the criterion unusable.

On 18 April 1783 Congress formally switched back to using relative population shares among the states as the apportionment criterion, albeit with slaves now counted as only threefifths of a person. This change was also made retroactive in application. The revision revoked the language in paragraph 1 of Article 8 of the Articles of Confederation and replaced it with:

all charges of war and all other expenses, that have been or shall be incurred for the common defence or general welfare, and allowed by the United States, in Congress assembled, shall be defrayed out of a common treasury, which shall be supplied by the several states in proportion to the whole number of white and other free citizens and inhabitants, of every age, sex and condition, including those bound to servitude for a term of years, and three-fifths of all other persons not comprehended in the foregoing description, except Indians, not paying taxes, in each State; which number shall be triennially taken and transmitted to the United States in Congress assembled, in such mode as they shall direct and appoint (JCC vol. 24, pp. 260-61).

What criteria were actually in use to apportion Congressional resource demands among the states is assessed in Table 1, which presents the percentage distribution across the states of several specific Congressional requests and compares them with the modern estimate of the population distribution across the states in 1780 (column 1). Columns 2 and 7 present distributions of Continental Dollars to be redeemed - the first and last distribution of said mentioned by Congress. Columns 3 and 8 present distributions of non-Continental Dollar 
revenue requests—one from 1777 and one from 1783. Lastly, columns 4, 5, and 6 present distributions of troop requests from the states to fill the ranks of the national Continental army.

The comparisons show that while each distribution is slightly different, and apparently randomly so, they are all basically consistent with the distributions being based on each state's population share in the union. Columns 2 and 8 were supposed to be based on the population distribution with the only difference being that column 8 but not column 2 was to be based on counting slaves as three-fifths of a person. Yet, it is difficult to see a systematic difference between the distributions in columns 2 and 8 . Columns 3 through 7 were set under the auspices of the Articles of Confederation which was supposed to use improved land value as the criterion for apportionment. Yet, it is hard to see a systematic difference across these columns and between these columns and columns 2 and 8 . Finally, it is hard to see any systematic difference across any of these resource distributions established by Congress and the modern estimate of the distribution of population across the states in 1780 .

While the evidence in Table 1 indicates that throughout the war Congress demanded that resources and revenues be provided by the states in proportion to that state's population share in the union, Congress did not know with great exactitude what those shares were, certainly not at the level of the modern estimate of population shares (column 1). This lack of exact knowledge may explain some of the seemingly random variation across the distributions. States may have sought adjustments from year to year in their Congressional apportionments.

That said it is still interesting to compare what Congress thought the shares should be with the modern estimates of those shares, i.e. compare column 1 with the other columns. Requests were set consistently higher for Massachusetts, Maryland, and South Carolina, and lower for New York, Delaware, and Georgia, than what they should have been. On average, 
requests were set slightly higher for New Hampshire and Connecticut, and slightly lower for Virginia and North Carolina, than what they should have been. For several states both in the North and in the South, the distributions track their white-population-only share, while for other states they track their total population share, in the union. The cases of New York and Georgia may also reflect the fact that large portions of these two states, i.e. their most important economic areas, were occupied by the British during a substantial portion of the war and so they may have been excused from their full share. The other cases probably represent just misestimates of population totals by Congress. In conclusion, Congressional resource demands from the states throughout the war can be taken as apportioned by state population shares in the union. In other words, national revenue and resources were to be extracted by population and thus geographically by population location.

\section{Congressional Wartime Spending: Location and Source}

Congressional resource extraction was pro-rated by population and thus geographically based on population location within the union. Congressional spending, however, was driven by military necessity and so targeted geographically at the theaters of war. These theaters of war were not spread evenly across the states or across the population of the union. They were regionally if not locally focused, moving geographically over time as military strategy changed. Table 2 tracks the location of the major theaters of war. Roughly, the war moved from north to south. The first year of war, April 1775 through April 1776, was waged largely in New England with Boston being the major focus, but with smaller campaigns waged in northern New England and into Canada. The next four years of war, May 1776 through May 1780, were waged almost exclusively in the Middle States_-between the environs of New York City and Philadelphia with one major engagement in upstate New York. Thereafter, the war turned to the Southern States, 
but on a smaller scale than what had gone before. The main American army would not travel into the Southern States to fight until after August of 1781.

[Place Table 2 Here]

Congressional spending in this period was primarily in the paper money it created - the Continental Dollar. The muddled history of Congressional emissions of Continental Dollars has been recently straightened out and the corrected amounts and time path of these emissions are given in Table 3 (Grubb 2008b). If Congressional spending exclusively followed the theater of war, then approximately $\$ 10$ million Continental Dollars (face value) were injected into the New England economy, principally in the Boston area, during the first year of the war with little thereafter. The remaining \$190 million Continental Dollars (face value), emitted between May 1776 and November 1779, were injected into the economies of the Middle States, excluding New York City which was occupied by the British for most of the period. Continental Dollars were not injected into the economies of the Southern States.

[Place Table 3 Here]

This crude approximation of spending flows highlights the issue of geographic fiscal/monetary imbalance. Throughout this period, the Southern States received far less Congressional spending compared with the resource and revenue flows, or future responsibility for revenue flows, demanded of them by Congress. This imbalance was also true for New England after the first year of the war. By contrast, the Middle States, after the first year of the war, received far more Congressional spending than what they owed Congress in return. This geographic imbalance in Congressional revenue demands versus spending flows may have eroded the commitment to the union by the Southern States, and to a lesser extent the New England States, compared with that of the Middle States. 
In addition, given the hyperinflation that accompanied the escalating emissions of Continental Dollars, particularly after mid-1776, the imbalance in fiscal spending by Congress across regions suggests that this hyperinflation was initially felt and likely more severely felt for some time in the Middle States compared with either the Southern States or New England. ${ }^{2}$ Efforts to reform Congress' Continental Dollar monetary policy, namely to somehow revalue the currency or alter how revenue quotas in Continental Dollars were to be paid, would have been most beneficial to the Middle States and such efforts should have been pushed by those states. ${ }^{3}$

This crude approximation can be refined by showing that Continental Dollar paper currency dominated Congressional monetary spending and so could have had the hypothesized monetary effects on regional prices. Table 4 estimates the source of Congressional monies spent from 1775 through 1779 . While the exact amount and yearly placement of domestic loans as well as foreign loans and gifts cannot be determined with perfect certainty, the general pattern can be taken with some confidence. From 1775 through 1779 Continental Dollar currency represented approximately $77 \%$ of the monies spent by Congress. It was $100 \%$ in the first two years. In other words, the first five years of the war were fought on the back of the Continental Dollar. As such, these massive monetary injections, if regionally targeted, could have produced strong regional differences, at least in the short-run, in national currency inflation.

[Place Table 4 Here]

Having established the dominance of spending in Continental Dollar currency, the above approximation on the geographic imbalance of this spending can be further refined by showing that in fact the majority of Congressional spending actually flowed to where the theater of war was located. While harder to establish conclusively, a strong case can be made for such a flow. A first stab can be taken by looking at the salary or monthly pay of soldiers in the Continental 
army - annualized to get an expected yearly cost. Because the vast majority of Continental troops, those at and below the rank of captain, were likely to be located where the theater of war was, their total expense can give an impression of where Continental Dollars were flowing. Table 5 provides these estimates and shows that around 43 to $46 \%$ of all the Continental Dollars authorized by Congress in 1776 and 1777 can be accounted for as just monthly salary flowing to soldiers in the field. The numbers are lower in 1775,1778 , and 1779 , being 23,10 , and $5 \%$, respectively. These numbers are indicative of a substantial flow of Continental Dollar currency going narrowly into where the theater of war was located. While tantalizing, a fuller accounting of Congressional wartime spending is needed to strengthen the case.

[Place Table 5 Here]

\section{Congressional Wartime Spending By Type of Expense}

A full accounting of Congressional spending by type of expense for each year of the war is hard to find. As far as I know, only one such accounting exists. It was prepared by Henry Knox, Secretary of War in the first Washington administration, in 1790 and was included in a document compiled by Joseph Nourse, registrar of the Treasury, for Congress explaining the "receipts and expenditures of public monies during the administration of the finances by Robert Morris." This report has often been overlooked, perhaps because it was made by the Secretary of War, Henry Knox - a relatively obscure person to most Americans of today. ${ }^{4}$

Knox, however, may be the most underappreciated revolutionary hero and founding father within the current scholarly literature. He was there at the beginning of hostilities and quickly rose to command Washington's artillery corps and was a key advisor to Washington on strategy, logistics, and supplies. In some ways he was Washington's right-hand man, and Washington viewed him as critical to his military success. In addition, Knox became a principal 
in organizing ordnance supplies, including the foundation and running of armories during the war at Springfield, Massachusetts and Carlisle, Pennsylvania.

After the revolution, Knox was put in charge of the War Department under the Confederation government and then became the only department head that was held over into the first Washington administration under the new U.S. Constitution as Washington's Secretary of War (Puls 2008). He and Joseph Nourse were the two longest, continuous serving administration appointees from the end of the war into the 1790s. Finally, from the beginning of the revolution into the early 1790s, the war office was extensively involved in the disbursement of Congressional spending authorizations, whereas the Congressional Treasury was more in charge of managing the revenue and finance side of the ledger. Henry Knox was in the right place to observe Congressional spending and had been continuously and directly involved in these spending issues longer than any other administrator, civilian or military.

As such, Knox's 1790 report should not only carry considerable weight in any assessment of Congressional wartime spending but is doubly important in that the U.S. War Office and all its records were destroyed by fire in November of 1800. Knox's report, being imbedded in Nourse's report to Congress in 1790, is as far as I can tell the only surviving account of the record of Congressional spending from 1775 through 1781 kept by the War Office. ${ }^{5}$ It forms the basis for what follows.

Knox's report listed between 11 and 14 categories or types of spending for each year of the war-1775 being included in 1776 as Congressional spending on the war did not begin until late June of 1775. From 1775 into 1780 amounts were kept in Continental Dollar units of account (Grubb 2008b, pp. 285-86). Table 6 presents Knox's data for 1775 through 1780 by year in percentages spent by category out of the total spending listed that year. Knox's data are 
slightly rearranged by consolidating some categories so that only 12 are listed and to group the categories by whether the spending was more or less targeted into the current theater of warthus trying to get at the issue of geographic spending imbalances by region.

[Place Table 6 Here]

While Table 5 estimated the expected yearly cost of monthly pay just to the Continental army, at the rank of captain and below, and found it to be a substantial component of Congressional spending through 1777, Knox's first category in Table 6 reports the actual spending on all pay plus recruiting costs and "other contingencies" of the Continental army. It shows that direct army personnel and contingency expenses dominated Congressional spending through 1777, and remained sizable thereafter - coming in second behind military supplies (the Commissary and Quartermaster categories) after 1777. Interestingly, direct army pay dominated Congressional spending through 1777 , thereafter it was the cost of supplying the army with provisions and equipment that dominated Congressional spending — representing well over half the budget in the years after 1777 (Carp 1984, pp. 17-135).

Direct military pay was not the only budget item that was likely to be war-theater specific spending. Because of logistics and transport costs, supplying the army with food, clothing, equipment, and other necessary support materials was largely a local or at least regional affair (Carp 1984, pp. 53-135). Thus, when the Commissary, Quartermaster, Special Expeditions, and Clothing, Hospital, and Prisoner Departments are included with the army pay category (the first 5 categories in Table 6), the share of total Congressional spending that was likely targeted narrowly at the region where the theater of war was located amounted to two-thirds in 17751776 , rose to three-quarters by 1777 , and peaked at $90 \%$ of the budget in 1779 . These numbers are likely biased low because the largest spending category not included among the war-theater 
specific categories was "advances to the states." This category included some states that were within the current theater of war. Thus, separating that category into war-theater versus non-wartheater spending would increase the war-theater spending percentage (research still in progress).

\section{Congressional Spending: Totally Up the Sources}

Knox's report tallies total Congressional spending per year in Continental Dollar units of account (reported in Table 6). Assuming Knox's totals are the true totals, comparing them with the authorized emissions of Continental Dollars by Congress within the same approximate time frame indicates that Continental Dollars once authorized and printed were likely rapidly spent. The Congressional treasury was constantly empty of Continental Dollars. Congressional authorization of new emissions of paper money could not keep up with spending. This has never been shown before, though many have suspected it. In part, this explains the explosion in the Continental Dollar money supply and the resulting hyperinflation. Remember, no Continental Dollars were required to be redeemed by the states and returned to the Congressional treasury, where they were to be burnt, before 1780 .

While the deficit in Continental Dollar currency needed to meet current spending was small through 1776 - being only $\$ 127,447$, it ballooned to over $\$ 8.4$ million in 1777 and just under $\$ 3.5$ million in 1778. After that it exploded to crises levels—-being over $\$ 51$ million in 1779 and over $\$ 82$ million in 1780 . Much of this change was driven by the expanding share of the Commissary and Quartermaster Departments in the Congressional spending budget. Military supplies, not men, were breaking the budget. How were these deficits made up?

The remaining part of Table 6 attempted to account for how these deficits in Continental Dollars were covered — something that has not be charted well before. The evidence is fragile and sketchy, yet of some interest and generally coherent. First, domestic borrowing, while 
relatively small, helped reduce the deficit dramatically in the early years, yielding a deficit of only about $\$ 1$ million in 1777 and then even putting the budget into surplus by $\$ 1.2$ million in 1778. Thereafter, however, domestic borrowing was not enough to keep the deficit from ballooning, yielding deficits of about $\$ 30$ million in 1779 and $\$ 70$ million in 1780 .

Foreign loans and gifts may have helped reduce these remaining deficits. This is more difficult to determine because it is not known how much of these foreign loans and gifts were in cash given to the Congressional treasury that found their way into Knox's accounting of Congressional spending. Foreign loans and gifts that were in the form of direct goods or credits in Europe seem unlikely to have been included in Knox's spending tally. A biased low estimate of the residual deficit can be made by assuming that all foreign loans and gifts were cash that the treasury could spend. Under this assumption, the Congressional budget, using Knox's spending data, was in good shape through 1778 , basically being in a small surplus from 1776-1778. Thereafter, the residual deficits mounted, being \$2.3 million in 1779 and \$47.5 million in 1780 . While the exactitude of the accounting cannot be relied on, the general pattern over time and approximate magnitudes appear sound. What it indicates is that a budgetary fiscal/monetary crisis was held in check well into 1778 and then rapidly escalated thereafter. The residual deficit in these latter years, especially after 1778, was largely made up by confiscation of supplies and services. Paper IOUs, quartermaster notes, certificates, and warrants were handed out to the lucky ones whose goods and services were requisitioned, legally impressed, or just taken. These sums appear large. A conservative estimate using the data in Table 6 is that about $\$ 50$ million in current Continental Dollar unit-of-account value of these IOUs were used to balance the budget in 1779-1780. This is consistent with the Commissary and Quartermaster Departments having 
risen to dominate the lion's share of Congressional spending after 1778. Again, this spending was largely focused on where the theater of war was located (Carp 1984, pp. 53-135).

\section{State Commitment to the Union}

Congressional spending largely flowed to the theater of war, yet Congressional resources, both men and money, were to be drawn from the states based on the states' relative population share in the union. This imbalance in where the resources were to come from and were they were to be applied may have affected a state's commitment to the union. States or regions that were to provide more to Congress than they were to receive from Congress may have had their commitment to the union weakened and vice versa.

Measures of state commitment to the union are constructed and used to create an index of that commitment. The goal is to see if these measures correlate with the regional locus of Congressional spending, i.e. those regions who received disproportionately more Congressional spending being more committed to the union. In the period 1775 through 1780, the Southern States received a relatively low share of Congressional spending whereas the Middle States received a relatively high share of Congressional spending. The New England States fell somewhere in between - relatively high in 1775-1776 and perhaps moderately high thereafter sustained by the increased spending on military supplies in the Congressional budget.

Three measures of state commitment to the union are constructed. The first captures how well each state filled its quota of men to be provided to the national Continental army from 1777 through 1780, i.e. through the period dominated by Congressional spending via Continental Dollar paper money. This information comes from the 1790 report by the Secretary of War and is reproduced in slightly altered form in Table 7. Each state's quota of men to be provided was set roughly proportional to each state's population in the union (see Table 1 above). 
[Place Table 7 here]

The second measure captures military resource commitment unrelated to the first measure which was based on population quotas and is used to get any difference in commitment to revolution per se versus commitment to the union. This measure takes estimates of the total amounts of troops raised by each state (both local militia and soldiers put into the national Continental army) and uses the Continental army portion relative to total troops raised as a measure of state commitment to the union relative to state commitment to revolution. This measure covers 1775 through 1780 - again through the period dominated by Congressional spending via Continental Dollar paper money. This information also comes from the 1790 report by the Secretary of War, Henry Knox, and is reproduced in slightly altered form in Table 8 .

[Place Table 8 Here]

The third measure captures the financial commitment by each state to the union through the end of the war - to 1784 - in terms of the extent to which each state redeemed its quota of Continental Dollars that Congress spent from 1775 through 1779. This quota was set roughly proportional to each state's population in the union, and states were not required to start filling their quota until after November of 1779 (see Table 1 above). Not much action to further fill this quota occurred after 1784 until after mid-1786 when it became clear that some general reckoning of accounts between the states and Congress would occur in the near future (Grubb 2008a). This measure along with the first two described above are reported in Table 9 by state. Therein unweighted averages by measure per region are also reported along with an index of commitment constructed as a simple un-weighted arithmetic average of the three individual measures.

[Place Table 9 Here] 
While there are some notable outliers on some measures for some states in some regions, the general pattern of the index across regions is consistent with the ranking of Congressional spending flows by region. The Southern States were the least committed to the union and also received a relative low share of Congressional spending. The Middle States who likely received the highest share of Congressional spending were also the most committed states to the union. New England was almost as committed to the union as the Middle States which, given that they received a moderately-high share of Congressional spending, may not be surprising.

Interesting intra-regional differences exist. For example, the Chesapeake States (Maryland and Virginia) were on balance more committed to the union than the Carolinas among the Southern States, and Rhode Island was less committed to the union on balance than the other New England States. Considerable differences across measures also exist. For example, the second measure indicates that the Chesapeake States were as committed to the union as the Middle States, but both groups were less committed than the New England States-sans Rhode Island. Such patterns indicate that there may still be a substantial role for revolutionary fervor and sacrifice to a larger cause in explaining commitment to a "nation" as opposed to commitment just to one's own colony. Congressional resources were predominantly flowing into the Middle States from mid-1776 through 1780, yet New England—sans Rhode Island—and the Chesapeake States maintained high levels of sacrifice and commitment to the union. Finally, regarding the commitment to redeeming Congress' spending of paper Continental Dollars, the Middle States along with the most northern of the New England States were the most committed to the union relative to the Southern States and the most southern of the New England States.

Certainly there are other causes for these patterns of state commitment to the union than just the imbalance of Congressional resource/revenue inflows versus spending outflows. For 
example, military commitment to the union is likely to be correlated with where the fighting is actually taking place, which in turn is correlated with Congressional spending flows. Yet, while fighting largely shifted out of New England after mid-1776 and into the Middle States thereafter, New England's military commitment to the union using the first two measures in Table 9 remained high — higher on average than that in the Middle States. Setting a revolutionary-fervor argument aside, the fact that Congressional spending increasingly involved supplying the army rather than just soldiers' pay (the Commissary and Quartermaster Departments listed in Table 6) and that these supplies for an army fighting mainly in the Middle States were often drawn from New England and to a lesser extent from the Chesapeake States may help explain the strength of these states' commitment to the union through the period.

On the other hand, the third measure in Table 9 likely reflects the locus of Congressional spending. States would find it difficult to acquire Continental Dollars via taxing their citizens if few Continental Dollars had been directly spent by Congress in their state. Significant amounts of Continental Dollars had been spent in Massachusetts and in the Middle States, if nothing else directly as soldiers' pay. Thus it may not be surprising that Massachusetts, New Hampshire, and the Middle States dominated this measure of commitment to the union; it may have simply been a by-product of the locus of Congressional spending and thus the ease of compliance. Few Continental Dollars were spent in the Southern States, so it is not unreasonable to suppose that these states found it difficult to comply with their redemption quotas.

\section{Conclusions}

Geographic imbalances in national fiscal/monetary policy are important for understanding the American Revolution and its political aftermath. Federalism, confederations, and state commitment to a national government can be fragile and affected by how and where 
resources are extracted compared with how and where those resources are spent. The analysis here helps foreshadow and explain the post-revolution difficulties of holding the union together, i.e. the difficulties in achieving a final financial accounting and accommodation across the states in paying for the revolution, the need to accommodate the Southern States in certain ways to hold them in the union, as well as explain the continuing rogue behavior of states such as Rhode Island and North Carolina. This analysis suggests that integrating the disunity created by the operation of the national fiscal structure during the revolution with the post-war struggle for political unity in the early republic might be a fruitful direction for future research.

One outcome of this analysis is the hypothesis that monetary effects and price inflation were geographically varied. Most of Congress' spending through 1779 was in the form of paper money. Given regionally targeted spending correlated with the theaters of war, local or at least regional differences in economic stimulus and price inflation should have occurred. These differences were unlikely to have been evened out over the entire country or arbitraged away quickly, especially given wartime disruptions to trade flows. As of now, this hypothesis cannot be tested or measured well because only one true price index currently exists that spans the years of the revolution, namely for Philadelphia (Bezanson 1951). ${ }^{6}$ The analysis here indicates that caution should be used when generalizing from this Philadelphia price index to what was happening nationally to the Continental Dollar. Philadelphia and its hinterland from mid-1776 on may have experienced the brunt of Continental Dollar paper money injections and so been the leading indicator of, and suffered the most from, price inflation in Continental Dollars compared with other regions. The perspective offered here on the geographic imbalance in national fiscal/monetary policy provides direction to, and hints at the likely fruitfulness of, continued research using this approach to the financing the American Revolution. 


\section{References}

Bezanson, Anne, Prices and Inflation during the American Revolution: Pennsylvania, 17701790. Philadelphia: University of Pennsylvania Press, 1951.

Boyd, Julian P., The Papers of Thomas Jefferson. Princeton, NJ: Princeton University Press, Vol. $10,1954$.

Carp, E. Wayne, To Starve the Army at Pleasure: Continental Army Administration and American Political Culture, 1775-1783. Chapel Hill, NC: University of North Carolina Press, 1984.

Esposito, Vincent J., ed., The West Point Atlas of American Wars, Volume 1: 1689-1900. New York: Henry Holt, 1995.

Ferguson, E. James, The Power of the Purse. Chapel Hill, NC: University of North Carolina Press, 1961.

Ferguson, E. James, ed., The Papers of Robert Morris, 1781-1784. Pittsburgh, PA: University of Pittsburgh Press, 1973, vol. 1.

Grubb, Farley, “The Continental Dollar: How Much Was Really Issued?” NBER Working Paper \#13047, December 2007, http://www.nber.org/papers/w13047.

Grubb, Farley, “The Continental Dollar: What Happened to It after 1779?” NBER Working Paper \#13770, February 2008a, http://www.nber.org/papers/w13770.

Grubb, Farley, “The Continental Dollar: How Much Was Really Issued?” Journal of Economic History, 68 (Mar. 2008b), pp. 283-291.

Grubb, Farley, “The Birth of the Continental Dollar," Working Paper, Economics Dept., Univ. of Delaware, 2008c.

Historical Statistics of the United States: Colonial Times to 1970. Washington, D.C.: U.S. Department of Commerce, 1975.

Journals of the Continental Congress, 1774-1789. Vols. 1-34. Washington D.C.: Government Printing Office, 1904-1937. [JCC]

Jensen, Merrill, The New Nation: A History of the United States During the Confederation, 1781-1789. Boston: Northeastern University Press, 1981.

Knox, Henry, "Report of the Secretary of War-War-Office of the United States, May 10, 1790" which is listed as item E. in Joseph Nourse, "Statements of the Receipts and Expenditures of Public Monies, During the Administration of the Finances by Robert Morris," submitted to the House of Representatives by the Treasury Department, Registrar's Office, August 30, 1790 and 
reprinted in Elizabeth M. Nuxoll and Mary A. Gallagher, eds., The Papers of Robert Morris, 1781-1784. Pittsburgh, PA: University of Pittsburgh Press, 1999, vol. 9, pp. 905-940.

Papers of the Continental Congress, 1774-1789. Unpublished Manuscripts held at the National Archives and Records Service, Washington, DC, microfilm \#247.

Puls, Mark, Henry Knox: Visionary General of the American Revolution. New York: Palgrave Macmillan, 2008.

Rousseau, Peter L. "A Common Currency: Early US Monetary Policy and the Transition to the Dollar," Financial History Review, 13 (Apr. 2006), pp. 97-122.

Newman, Eric P., The Early Paper Money of America. Iola, WI: Krause Publications, 1997.

Nuxoll, Elizabeth M. and Mary A. Gallagher, eds., The Papers of Robert Morris, 1781-1784. Pittsburgh, PA: University of Pittsburgh Press, 1999, vol. 9.

Tindall, George Brown, America: A Narrative History. New York: W. W. Norton, $2^{\text {nd }}$ edn., 1988. 
Table 1 Percentage Distribution across the States of Fiscal, Monetary, and Military Quotas, 1775-1783: Congressional Resource and Revenue Demands

\begin{tabular}{|c|c|c|c|c|c|c|c|c|}
\hline \multirow[b]{2}{*}{ State } & \multirow{2}{*}{$\begin{array}{l}1780 \% \text { of } \\
\text { Population: } \\
\text { Total } \\
\{\text { White } \\
\text { only\} }\end{array}$} & \multirow{2}{*}{$\begin{array}{l}\text { Initial } \\
\text { Continental } \\
\text { Dollar (1775) } \\
\text { Redemption } \\
\text { Quota \% }\end{array}$} & \multicolumn{2}{|c|}{$\begin{array}{l}\text { Recommended } \\
\text { Nov. 22, }\end{array}$} & \multicolumn{2}{|c|}{ Troop Quota \% } & \multirow{2}{*}{$\begin{array}{l}\text { Remaining } \\
\text { Continental } \\
\text { Dollar (1781) } \\
\text { Redemption } \\
\quad \%\end{array}$} & \multirow{2}{*}{$\begin{array}{r}\text { Funding } \\
\% \\
\mathrm{Se} \\
\text { Apri } \\
1783\end{array}$} \\
\hline & & & & 1777 & 1778 & 1780 & & \\
\hline New Hampshire & $\begin{array}{l}3.16 \\
\{3.96\}\end{array}$ & 4.14 & 4.00 & 3.41 & 3.49 & 3.75 & 2.67 & 3.51 \\
\hline Massachusetts & $\begin{array}{c}11.43 \\
\{14.17\}\end{array}$ & 14.47 & 16.40 & 17.07 & 17.44 & 18.75 & 15.33 & 14.96 \\
\hline Rhode Island & $\begin{array}{c}1.90 \\
\{2.28\}\end{array}$ & 2.40 & 2.00 & 2.27 & 1.16 & 2.50 & 1.33 & 2.15 \\
\hline Connecticut & $\begin{array}{c}7.43 \\
\{9.11\}\end{array}$ & 8.27 & 12.00 & 9.09 & 9.30 & 10.00 & 11.33 & 8.81 \\
\hline New York & $\begin{array}{c}9.29 \\
\{10.75\}\end{array}$ & 8.27 & 4.00 & 4.55 & 5.81 & 6.25 & 5.00 & 8.55 \\
\hline New Jersey & $\begin{array}{c}5.02 \\
\{5.86\}\end{array}$ & 5.38 & 5.40 & 4.55 & 4.65 & 3.75 & 6.00 & 5.56 \\
\hline Pennsylvania & $\begin{array}{c}11.77 \\
\{14.49\}\end{array}$ & 12.41 & 12.40 & 13.64 & 11.62 & 13.75 & 15.33 & 13.68 \\
\hline Delaware & $\begin{array}{c}1.63 \\
\{1.92\}\end{array}$ & 1.24 & 1.20 & 1.14 & 1.16 & 1.25 & 1.13 & 1.50 \\
\hline Maryland & $\begin{array}{c}8.83 \\
\{7.48\}\end{array}$ & 10.34 & 10.40 & 9.09 & 9.30 & 10.00 & 10.53 & 9.43 \\
\hline Virginia & $\begin{array}{c}20.97 \\
\{16.11\}\end{array}$ & 16.54 & 16.00 & 17.05 & 17.44 & 13.75 & 16.67 & 17.10 \\
\hline North Carolina & $\begin{array}{l}10.08 \\
\{8.51\}\end{array}$ & 8.27 & 5.00 & 10.23 & 10.47 & 7.50 & 6.67 & 7.27 \\
\hline South Carolina & $\begin{array}{c}6.47 \\
\{3.76\}\end{array}$ & 8.27 & 10.00 & 6.82 & 6.98 & 7.50 & 8.00 & 6.41 \\
\hline Georgia & $\begin{array}{c}2.02 \\
\{1.60\}\end{array}$ & ----- & 1.20 & 1.14 & 1.16 & 1.25 & ----- & 1.07 \\
\hline $\begin{array}{l}\text { Respective } \\
\text { Totals }\end{array}$ & $\begin{array}{l}, 708,369 \\
2,204,949\}\end{array}$ & $\$ 3,000,000$ & $\$ 5,000,000$ & 59,840 & 44,892 & $83,520 \$ 1$ & $95,000,000 \$ 1$ & $\begin{array}{l}1,500,000 \\
\text { (annually) }\end{array}$ \\
\hline
\end{tabular}

Sources: Derived from Historical Statistics of the United States: Colonial Times to 1970, Part 2 (Washington DC:

Government Printing Office, 1975), p. 1168 (Maine was included in Massachusetts; Vermont in New York; 
Kentucky in Virginia; and Tennessee in North Carolina for population counts); "Report of the Secretary of WarHenry Knox-War-Office of the United States, May 10, 1790" which is listed as item E. in Joseph Nourse, "Statements of the Receipts and Expenditures of Public Monies, During the Administration of the Finances by Robert Morris," submitted to the House of Representatives by the Treasury Department, Registrar's Office, August 30, 1790 and reprinted in Elizabeth M. Nuxoll and Mary A. Gallagher, eds., The Papers of Robert Morris, 17811784 (Pittsburgh, PA: University of Pittsburgh Press, 1999), vol. 9, pp. 905-940; Ferguson (1973, vol. 1, pp. 193194); Journals of the Continental Congress [JCC hereafter] (vol. 9, p. 955; vol. 15, p. 1150; vol. 24, p. 259). Notes: The total amount of Continental Dollars that Congress thought it had emitted was $\$ 200$ million—-the last emission being 29 November of 1779 , but due to an accounting error the actual total was $\$ 199,990,000$ (Grubb 2007, 2008b). The amount to be assigned to Georgia was left unstated and presumably reflects the difference between the $\$ 195$ million sum and the total Congress thought it had emitted. Georgia, being invaded, may have also been excused from its quota and the $\$ 195$ million total by June of 1781 may have reflected $\$ 5$ million already paid in by the states. 
Table 2 Major Theaters of War by Region, 1775-1781

\begin{tabular}{|c|c|c|c|c|}
\hline Dates & $\begin{array}{l}\text { Major } \\
\text { Campaigns } \\
\text { Theater/Region }\end{array}$ & $\begin{array}{l}\text { Major } \\
\text { Battles } \\
\text { (Date) }\end{array}$ & $\begin{array}{l}\text { simate } \\
\text { san Forces } \\
\text { d }\end{array}$ & $\begin{array}{l}\text { American } \\
\text { Commander }\end{array}$ \\
\hline $\begin{array}{l}\text { April } 1775 \\
\text { Through } \\
\text { April } 1776\end{array}$ & $\begin{array}{l}\text { New England } \\
\text { [Massachusetts, } \\
\text { New Hampshire, } \\
\text { Rhode Island, } \\
\text { Connecticut] }\end{array}$ & $\begin{array}{l}\text { Siege of } \\
\text { Boston }\end{array}$ & $\begin{array}{l}16,000 \\
10,000\end{array}$ & $\begin{array}{l}\text { George Washington } \\
\text { George Washington }\end{array}$ \\
\hline $\begin{array}{l}\text { May } 1776 \\
\text { Through } \\
1780\end{array}$ & $\begin{array}{l}\text { Middle States } \\
\text { [New York, } \\
\text { New Jersey, } \\
\text { Pennsylvania, } \\
\text { Delaware] }\end{array}$ & $\begin{array}{l}\text { New York City } \\
\text { (May-Nov. 1776) } \\
\text { Trenton/Princeton, NJ } \\
\text { (Dec. 1776/Jan. 1777) } \\
\text { Brandywine, PA } \\
\text { (Sept. 1777) } \\
\text { Germantown, PA } \\
\text { (Oct. 1777) } \\
\text { Saratoga, NY } \\
\text { (Sept.-Oct. 1777) } \\
\text { Monmouth, NJ } \\
\text { (June 1778) } \\
\text { [Main army remained } \\
\text { Pennsylvania until Aug }\end{array}$ & $\begin{array}{l}19,000 \\
6,800 \\
11,000 \\
11,000 \\
11,000 \\
13,400 \\
\text { in New Je } \\
\text { g. } 1781]\end{array}$ & $\begin{array}{l}\text { George Washington } \\
\text { George Washington } \\
\text { George Washington } \\
\text { George Washington } \\
\text { Horatio Gates } \\
\text { George Washington } \\
\text {, New York, and }\end{array}$ \\
\hline $\begin{array}{l}1780 \\
\text { Through } \\
1781\end{array}$ & $\begin{array}{l}\text { Southern States } \\
\text { [Maryland, } \\
\text { Virginia, North } \\
\text { Carolina, South } \\
\text { Carolina, Georgia] }\end{array}$ & $\begin{array}{l}\text { Charleston, SC } \\
\text { (May 1780) } \\
\text { Camden, SC } \\
\text { (Aug. 1780) } \\
\text { Cowpens, SC } \\
\text { (Jan. 1780) } \\
\text { Guilford Court House, } \\
\text { (Mar. 1781) } \\
\text { Hobkirk's Hill, SC } \\
\text { (Apr. 1781) } \\
\text { Eutaw Springs, SC } \\
\text { (Sept. 1781) } \\
\text { Yorktown, VA } \\
\text { (Sept.-Oct. 1781) }\end{array}$ & $\begin{array}{l}5,000 \\
3,052 \\
1,040 \\
\mathrm{NC} \\
4,400 \\
1,551 \\
2,200 \\
8,845\end{array}$ & $\begin{array}{l}\text { Benjamin Lincoln } \\
\text { Horatio Gates } \\
\text { Daniel Morgan } \\
\text { Nathaniel Greene } \\
\text { Nathaniel Greene } \\
\text { Nathaniel Greene } \\
\text { George Washington }\end{array}$ \\
\hline
\end{tabular}

Sources: Esposito (1995, maps 4-9); Puls (2008); Tindall (1988, pp. 210-42). 
Table 3 Continental Dollars Emitted by Congress, 1775-1779: Corrected Estimates of Total Net New Emissions (Face Value)

\begin{tabular}{|c|c|c|c|c|c|}
\hline \multirow[t]{3}{*}{1775} & June 22 & $\$ 2,000,000$ & 1778 & July 30 & $5,000,000$ \\
\hline & July 25 & $1,000,000$ & & September 5 & $5,000,000$ \\
\hline & November 29 & $3,000,000$ & & September 26 & $10,000,100$ \\
\hline \multirow[t]{4}{*}{1776} & February 17 & $3,937,220$ & & November 4 & $10,000,100$ \\
\hline & May 9 & $5,000,000$ & & December 14 & $10,000,100$ \\
\hline & July 22 & $5,000,000$ & 1779 & January 14 & $8,500,400$ \\
\hline & November 2 & $5,000,000$ & & February 3 & $5,000,160$ \\
\hline \multirow[t]{5}{*}{1777} & February 26 & $5,000,000$ & & February 12 & $5,000,160$ \\
\hline & May 20 & $5,000,000$ & & April 1 & $5,000,160$ \\
\hline & August 1 & $1,000,000$ & & May 5 & $10,000,100$ \\
\hline & November 7 & $1,000,000$ & & June 4 & $10,000,100$ \\
\hline & December 3 & $1,000,000$ & & July 17 & $15,000,280$ \\
\hline \multirow[t]{9}{*}{1778} & January 8 & $1,000,000$ & & September 17 & $15,000,260$ \\
\hline & January 22 & $2,000,000$ & & October 14 & $5,000,180$ \\
\hline & February 16 & $2,000,000$ & & November 17 & $10,050,540$ \\
\hline & March 5 & $2,000,000$ & & November 29 & $10,000,140$ \\
\hline & April 4 & $1,000,000$ & \multicolumn{3}{|c|}{ End of Emissions } \\
\hline & April 11 & $5,000,000$ & & & \\
\hline & April 18 & 500,000 & \multicolumn{3}{|c|}{ Total Cumulative } \\
\hline & May 22 & $5,000,000$ & \multicolumn{3}{|c|}{ Net New Emissions } \\
\hline & June 20 & $5,000,000$ & \multicolumn{2}{|c|}{ Outstanding: } & $199,990,000$ \\
\hline
\end{tabular}

Sources: Grubb (2007, 2008b); JCC (vol. 2, pp. 103, 105, 207; vol. 3, p. 390; vol. 4, pp. 32, 157, 339; vol. 5, pp. 599, 651, 697; vol. 6, pp. 912, 918; vol. 7, pp. 161, 373; vol. 8, pp. 377-80, 597, 646; vol. 9, pp. 873, 993; vol. 10, pp. 28, 82-83, 174-75, 223, 309, 337-38, 365; vol. 11, pp. 524, 627, 731; vol. 12, pp. 884, 962, 1100, 1218; vol. 13, pp. 64, 139, 209, 408; vol. 14, pp. 548, 68788, 848-49; vol. 15, pp. 1019, 1053, 1076-77, 1171-72, 1285, 1324-25, 1436); Papers of the Continental Congress (m247, r146, i136, p. 647).

Note: The date is the day Congress first authorized the emission listed. 
Table 4 Percentage Distribution of Congressional Monies Spent, 1775-1779—Estimated by Source and Measured in Continental Dollars (face value)

\begin{tabular}{lcccccc}
\hline Source & 1775 & 1776 & 1777 & 1778 & 1779 & Total \\
\hline $\begin{array}{l}\text { Continental } \\
\text { Dollars Emitted }\end{array}$ & $100.00 \%$ & $99.03 \%$ & $58.79 \%$ & $74.69 \%$ & $76.66 \%$ & $76.68 \%$ \\
$\begin{array}{l}\text { Domestic Loans } \\
\text { Toreign Loans }\end{array}$ & $0.00 \%$ & $0.00 \%$ & $33.20 \%$ & $5.50 \%$ & $16.62 \%$ & $12.80 \%$ \\
$\begin{array}{l}\text { And Gift Aid } \\
\text { Total }\end{array}$ & $0.97 \%$ & $8.01 \%$ & $19.81 \%$ & $6.72 \%$ & $10.52 \%$ \\
$\begin{array}{l}\text { Converted to } \\
\text { Spanish Dollars } \\
\text { (specie value) }\end{array}$ & $\$ 6,000,000$ & $\$ 19,122,420$ & $\$ 22,113,250$ & $\$ 85,017,038$ & $\$ 128,564,501$ & $\$ 260,817,209$ \\
& $\$ 19,122,420$ & $\$ 7,371,083$ & $\$ 17,003,408$ & $\$ 6,428,225$ & $\$ 55,925,136$ \\
\hline
\end{tabular}

Sources: Derived from Table 3 above and Table 6 below.

Notes: These yearly percentages are estimates in that the information on domestic loans was not kept by calendar year, so some cross-year overlaps were unavoidable, see Table 6 . In addition, the monetary portion of the foreign aid that Congress could use to spend domestically is unknown, see Table 6. It is assumed here that all foreign loans and gift aid were in cash that Congress could spend, thus giving a biased low estimate to the Continental Dollar percentage of the budget. These numbers also exclude goods and services confiscated or otherwise acquired for IOU's in the form of Quartermaster Notes, Warrants, and Certificates, see Table 6. Finally, the conversion factor for going from Continental Dollar face value to Spanish Dollar (specie value) are crude yearly averages, see Table 6. 
Table 5 Congressional Troop Costs in just Soldier Salaries: Expressed in Continental Dollars (face value) Per Year, 1775-1779

\begin{tabular}{lccccc}
\hline & $1775^{*}$ & 1776 & 1777 & 1778 & 1779 \\
\hline $\begin{array}{l}\text { Number of Men in } \\
\text { Continental Pay }\end{array}$ & 27,443 & 46,901 & 34,820 & 32,899 & 27,699 \\
$\begin{array}{l}\text { Biased Low Annualized } \\
\text { Expected Troop Pay }\end{array}$ & $\$ 1,380,874$ & $\$ 8,106,346$ & $\$ 6,018,272$ & $\$ 5,686,247$ & $\$ 4,787,481$ \\
$\begin{array}{l}\text { As a Percentage of } \\
\begin{array}{l}\text { Continental Dollars } \\
\text { Emitted that Year }\end{array}\end{array}$ & $23.01 \%$ & $42.81 \%$ & $46.29 \%$ & $8.95 \%$ & $4.86 \%$ \\
\hline
\end{tabular}

Sources: Table 3 above; Knox (1790); JCC (vol. 2, pp. 89-90).

Notes: $*=1775$ is taken to cover only from June on. Congress set the monthly pay for troops in Continental pay on 14 June 1775 . The pay for privates through captains for a company consisting of 81 men sums to $\$ 582.25$ per month. Annualized, this is $\$ 14,000$ per company of 81 men per year in expect cost. This information is used to generate the annualized expect troop pay in the table. These numbers are biased low in that they do not include the pay for military personal above the rank of captain, nor do they include recruitment bonuses or any equipage cost. Not all troops were necessarily enlisted for the entire year, thus these number represent the expected cost if those enlisted that year in fact stayed enlisted for that year. 
Table 6 Yearly Distribution of Congressional Spending by Type of Expense, 1775-1780

Type of

\begin{tabular}{lcc} 
Expense & June 1775-1776 & 1777 \\
\hline 1. Spending That Was Relatively “Current”" War-Theater Specific
\end{tabular}

\begin{tabular}{lcc} 
Expense & June 1775-1776 & 1777 \\
\hline 1. Spending That Was Relatively "Current" War-Theater Specific
\end{tabular}

Percentage of Total Spent per Year

$\begin{array}{lccccc}\begin{array}{l}\text { Army Recruiting, Pay, and } \\ \text { Other Contingencies }\end{array} & 46.71 \% & 36.45 \% & 22.00 \% & 10.55 \% & 23.30 \% \\ \begin{array}{l}\text { Commissary Department } \\ \text { Quartermaster Department }\end{array} & 12.66 & 21.78 & 31.36 & 35.52 & 40.32 \\ \begin{array}{l}\text { Clothing, Hospital, and } \\ \text { Prisoner Departments }\end{array} & 3.82 & 11.86 & 26.59 & 37.94 & 16.88 \\ \begin{array}{l}\text { Special Expedition against Detroit } \\ \quad \text { Sub-total }\end{array} & 0 & 5.81 & 7.30 & 6.21 & 4.04 \\ & 66.56 & 75.90 & 88.64 & 90.22 & 0 \\ \end{array}$

\section{Spending That Was Less "Current" War-Theater Specific}

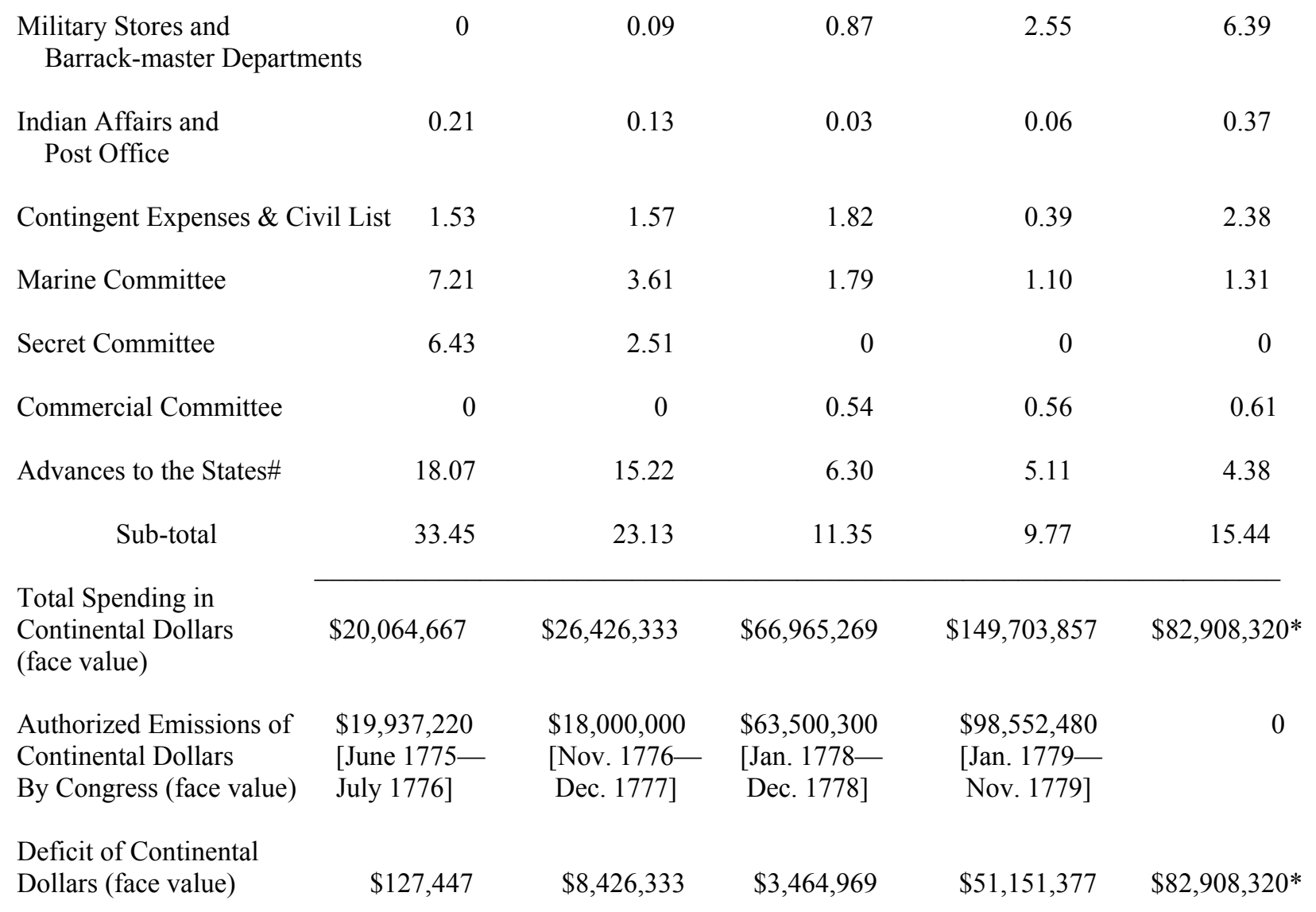




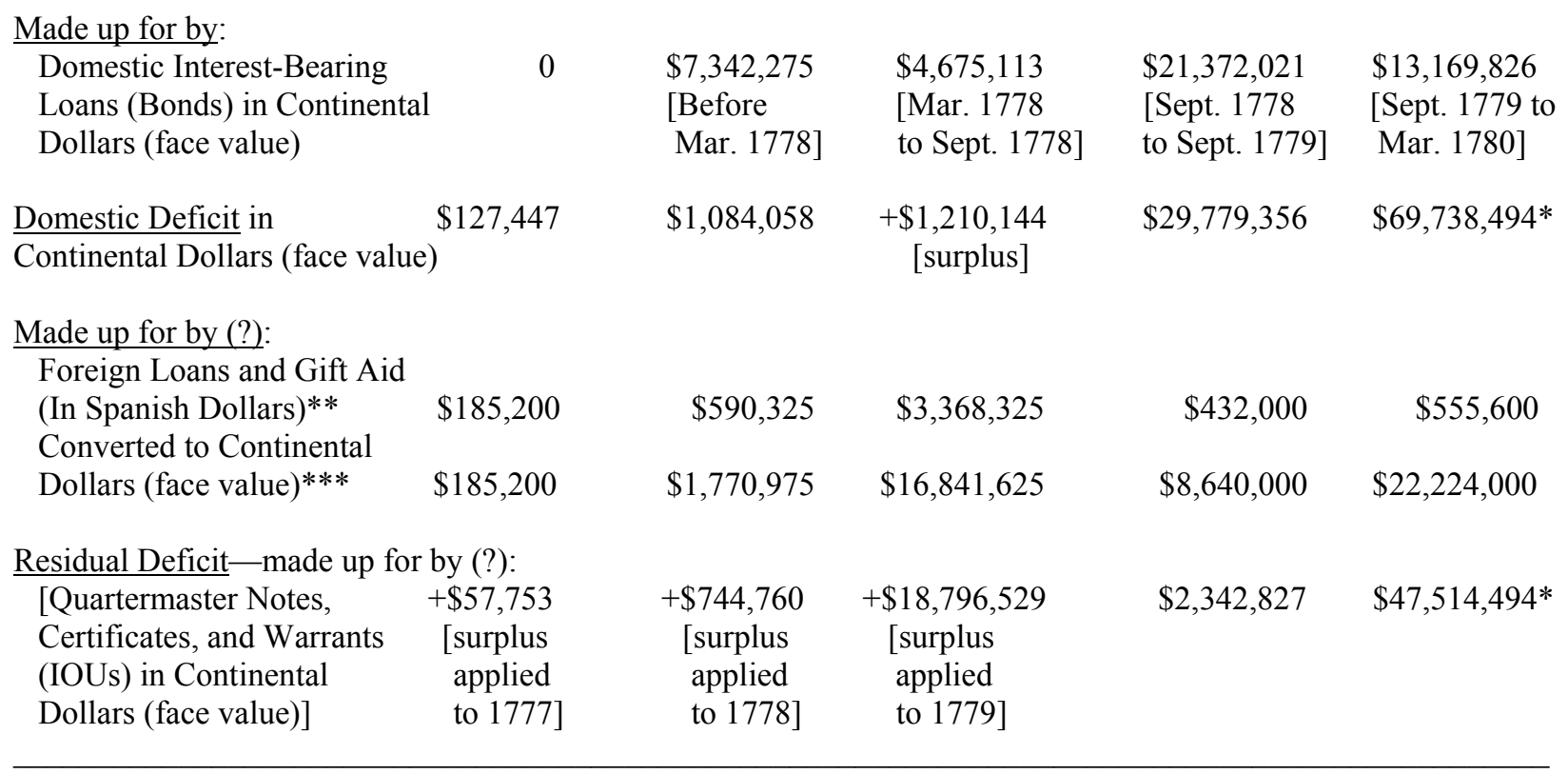

Sources: Table 3 above; Boyd (1954, vol. 10, pp. 42-43); Ferguson (1961, pp. 38-42); Grubb (2007, 2008a, 2008b);

Jensen (1981, pp. 38-39); JCC (vol. 24, pp. 285-86); Papers of the Continental Congress (microfilm \#247, r146, il36, p. 647); all other derived from the Knox (1790).

Notes: $*=$ only includes spending denominated in Continental Dollars of the old emission and not spending rated in the new Continental-State Dollar. Thus, 1780 is only a partial accounting. \#=I'm still trying to determine how much was channeled to states in the current war theater and how much was channeled to states outside the current war theater. ${ }^{* *}=$ conversion of loan, subsidy, and gift amounts from livres into Spanish Dollars (specie) at the rate stated in the sources cited with apportionment across the years, while somewhat unclear, following Ferguson (1961, pp. 40-42) and Jensen (1981, pp. 38-39) as closely as possible with the Dutch loan and the Spanish gift-aid placed in 1779, and the three million livres floating debt to individuals in Europe placed in 1780 somewhat arbitrarily. How much of the foreign loans were in cash versus in credit subsidies for foreign purchases is still to be determine. Thus, how much to count toward deficit balancing of domestic spending is unclear. The full amount is used here thus yielding a biased low estimate of the Residual Deficit. ${ }^{* * *}=$ Foreign Loans and Gifts are converted from Spanish Dollars (specie) to Continental Dollars following the depreciation table reported by Thomas Jefferson on 24 January 1786, using either the average or the mid-year rate for each year, respectively (Boyd 1954, vol. 10, pp. 42-43). The conversion factors used are 0, 3, 5, 20, and 40 Continental Dollars to one Spanish Dollar for 1775-1776, 1777, 1778, 1779 , and 1780 , respectively. 
Table 7 Distribution of Troops Furnish Who Were in Continental Pay by State (san State militia), 1775-1780

\begin{tabular}{|c|c|c|c|c|c|c|c|c|}
\hline \multirow[b]{2}{*}{ State } & \multirow[b]{2}{*}{1775} & \multicolumn{5}{|c|}{$\begin{array}{c}\text { Absolute Numbers Furnish by Year } \\
\text { (As a Percentage of that States' Required Quota) }\end{array}$} & \multirow{2}{*}{$\begin{array}{l}\text { Total } \\
\text { Men- } \\
\text { Years* }\end{array}$} & \multirow{2}{*}{$\begin{array}{l}\text { Yearly } \\
\text { Average }\end{array}$} \\
\hline & & 1776 & 1777 & 1778 & 1779 & 1780 & & \\
\hline New Hampshire & 2,824 & 3,019 & $\begin{array}{l}1,172 \\
(57.5 \%)\end{array}$ & $\begin{array}{l}1,283 \\
(81.9 \%)\end{array}$ & $\begin{array}{l}1,004 \\
(64.1 \%)\end{array}$ & $\begin{array}{l}1,017 \\
(64.9 \%)\end{array}$ & 10,319 & $\begin{array}{r}1,720 \\
(67.1 \%)\end{array}$ \\
\hline Massachusetts & 16,444 & 13,372 & $\begin{array}{r}7,816 \\
(76.6)\end{array}$ & $\begin{array}{r}7,010 \\
(89.5)\end{array}$ & $\begin{array}{r}6,287 \\
(80.3)\end{array}$ & $\begin{array}{l}4,453 \\
(56.9)\end{array}$ & 55,382 & $\begin{array}{c}9,230 \\
(75.8)\end{array}$ \\
\hline Rhode Island & 1,193 & 798 & $\begin{array}{r}548 \\
(42.5)\end{array}$ & $\begin{array}{r}630 \\
(120.7)\end{array}$ & $\begin{array}{r}507 \\
(48.6)\end{array}$ & $\begin{array}{l}915 \\
(87.6)\end{array}$ & 4,591 & $\begin{array}{r}765 \\
(74.9)\end{array}$ \\
\hline Connecticut & 4,507 & 6,390 & $\begin{array}{r}4,563 \\
(83.9)\end{array}$ & $\begin{array}{r}4,010 \\
(96.0)\end{array}$ & $\begin{array}{r}3,544 \\
(84.9)\end{array}$ & $\begin{array}{r}3,133 \\
(75.0)\end{array}$ & 26,147 & $\begin{array}{c}4,358 \\
(85.0)\end{array}$ \\
\hline New York & 2,075 & 3,629 & $\begin{array}{r}1,903 \\
(67.0)\end{array}$ & $\begin{array}{r}2,194 \\
(84.1)\end{array}$ & $\begin{array}{r}2,256 \\
(86.4)\end{array}$ & $\begin{array}{r}2,179 \\
(83.5)\end{array}$ & 14,236 & $\begin{array}{c}2,373 \\
(80.3)\end{array}$ \\
\hline New Jersey & 0 & 3,193 & $\begin{array}{r}1,408 \\
(51.8)\end{array}$ & $\begin{array}{r}1,586 \\
(76.0)\end{array}$ & $\begin{array}{r}1,276 \\
(81.5)\end{array}$ & $\begin{array}{r}1,105 \\
(70.6)\end{array}$ & 8,568 & $\begin{array}{c}1,428 \\
(70.0)\end{array}$ \\
\hline Pennsylvania & 400 & 5,519 & $\begin{array}{r}4,983 \\
(61.1)\end{array}$ & $\begin{array}{r}3,684 \\
(70.6)\end{array}$ & $\begin{array}{r}3,476 \\
(60.5)\end{array}$ & $\begin{array}{r}3,337 \\
(58.1)\end{array}$ & 21,399 & $\begin{array}{c}3,567 \\
(62.6)\end{array}$ \\
\hline Delaware & 0 & 609 & $\begin{array}{r}299 \\
(44.0)\end{array}$ & $\begin{array}{r}349 \\
(66.9)\end{array}$ & $\begin{array}{r}317 \\
(60.7)\end{array}$ & $\begin{array}{r}325 \\
(62.3)\end{array}$ & 1,899 & $\begin{array}{r}317 \\
(58.5)\end{array}$ \\
\hline Maryland & 0 & 637 & $\begin{array}{r}2,030 \\
(37.3)\end{array}$ & $\begin{array}{r}3,307 \\
(79.2)\end{array}$ & $\begin{array}{r}2,849 \\
(68.2)\end{array}$ & $\begin{array}{r}2,065 \\
(49.5)\end{array}$ & 10,888 & $\begin{array}{r}1,815 \\
(58.6)\end{array}$ \\
\hline Virginia & 0 & 6,181 & $\begin{array}{r}5,744 \\
(56.3)\end{array}$ & $\begin{array}{r}5,236 \\
(66.9)\end{array}$ & $\begin{array}{r}3,973 \\
(69.2)\end{array}$ & $\begin{array}{r}2,486 \\
(43.3)\end{array}$ & 23,620 & $\begin{array}{r}3,937 \\
(58.9)\end{array}$ \\
\hline North Carolina & 0 & 1,134 & $\begin{array}{r}1,281 \\
(20.9)\end{array}$ & $\begin{array}{r}1,287 \\
(27.4)\end{array}$ & $\begin{array}{r}1,214 \\
(38.8)\end{array}$ & $\begin{array}{r}0 \\
(0.0)\end{array}$ & 4,916 & $\begin{array}{r}819 \\
(21.8)\end{array}$ \\
\hline South Carolina & 0 & 2,069 & $\begin{array}{r}1,650 \\
(40.4)\end{array}$ & $\begin{array}{r}1,650 \\
(52.7)\end{array}$ & $\begin{array}{r}909 \\
(29.0)\end{array}$ & $\begin{array}{r}0 \\
(0.0)\end{array}$ & 6,278 & $\begin{array}{c}1,046 \\
(30.5)\end{array}$ \\
\hline Georgia & 0 & 351 & $\begin{array}{r}1,423 \\
(209.3)\end{array}$ & $\begin{array}{r}673 \\
(128.9)\end{array}$ & $\begin{array}{r}87 \\
(16.7)\end{array}$ & $\begin{array}{r}0 \\
(0.0)\end{array}$ & 2,534 & $\begin{array}{r}422 \\
(88.8)\end{array}$ \\
\hline $\begin{array}{l}\text { Sum Given } \\
\text { [Column Total] }\end{array}$ & 27,443 & $\begin{array}{c}46,891 \\
{[46,901]}\end{array}$ & $\begin{array}{l}34,820 \\
(46.0 \%)\end{array}$ & $\begin{array}{l}32,899 \\
(73.3 \%)\end{array}$ & $\begin{array}{l}27,699 \\
(66.3 \%)\end{array}$ & $\begin{array}{l}21,015 \\
(50.3 \%)\end{array}$ & $\begin{array}{c}190,767 \\
{[190,777]}\end{array}$ & $\begin{array}{r}31,796 \\
(59.0 \%)\end{array}$ \\
\hline
\end{tabular}

Source: Derived from Knox (1790).

Notes: $*=$ treats all numbers as full year enlistments. 
Table 8 Militia Furnish by the States, 1775-1780

\begin{tabular}{|c|c|c|c|c|c|c|c|c|}
\hline \multirow[b]{2}{*}{ State } & \multicolumn{8}{|c|}{$\begin{array}{l}\text { Absolute Numbers of Militia Furnish for Any Period of Time during Listed Year } \\
\text { (As a Ratio to Men Provided Who Were in Continental Pay) }\end{array}$} \\
\hline & 1775 & 1776 & 1777 & 1778 & 1779 & 1780 & $\begin{array}{c}\text { Total } \\
\text { Men-Years* }\end{array}$ & $\begin{array}{l}\text { Yearly } \\
\text { Average }\end{array}$ \\
\hline New Hampshire & $\begin{array}{r}0 \\
(0)\end{array}$ & $\begin{array}{r}1,000 \\
(0.331)\end{array}$ & $\begin{array}{r}3,311 \\
(2.825)\end{array}$ & $\begin{array}{r}500 \\
(0.390)\end{array}$ & $\begin{array}{r}222 \\
(0.221)\end{array}$ & $\begin{array}{r}760 \\
(0.747)\end{array}$ & $\begin{array}{c}5,793 \\
(0.561)\end{array}$ & 966 \\
\hline Massachusetts & $\begin{array}{r}0 \\
(0)\end{array}$ & $\begin{array}{r}7,000 \\
(0.524)\end{array}$ & $\begin{array}{r}4,775 \\
(0.611)\end{array}$ & $\begin{array}{r}6,427 \\
(0.917)\end{array}$ & $\begin{array}{r}1,451 \\
(0.231)\end{array}$ & $\begin{array}{r}3,436 \\
(0.772)\end{array}$ & $\begin{array}{l}23,089 \\
(0.417)\end{array}$ & 3,848 \\
\hline Rhode Island & $\begin{array}{r}0 \\
(0)\end{array}$ & $\begin{array}{r}1,102 \\
(1.381)\end{array}$ & $\begin{array}{r}1,500 \\
(2.737)\end{array}$ & $\begin{array}{r}2,426 \\
(3.851)\end{array}$ & $\begin{array}{r}756 \\
(1.491)\end{array}$ & $\begin{array}{r}0 \\
(0)\end{array}$ & $\begin{array}{c}5,784 \\
(1.260)\end{array}$ & 964 \\
\hline Connecticut & $\begin{array}{r}0 \\
(0)\end{array}$ & $\begin{array}{r}6,737 \\
(1.054)\end{array}$ & $\begin{array}{r}2,000 \\
(0.438)\end{array}$ & $\begin{array}{r}0 \\
(0)\end{array}$ & $\begin{array}{c}0 \\
(0)\end{array}$ & $\begin{array}{r}554 \\
(0.177)\end{array}$ & $\begin{array}{c}9,291 \\
(0.355)\end{array}$ & 1,544 \\
\hline New York & $\begin{array}{r}0 \\
(0)\end{array}$ & $\begin{array}{r}4,465 \\
(1.230)\end{array}$ & $\begin{array}{r}3,429 \\
(1.802)\end{array}$ & $\begin{array}{r}0 \\
(0)\end{array}$ & $\begin{array}{r}1,500 \\
(0.665)\end{array}$ & $\begin{array}{r}2,668 \\
(1.224)\end{array}$ & $\begin{array}{c}12,062 \\
(0.847)\end{array}$ & 2,010 \\
\hline New Jersey & $\begin{array}{r}0 \\
(0)\end{array}$ & $\begin{array}{r}5,893 \\
(1.846)\end{array}$ & $\begin{array}{r}1,500 \\
(1.065)\end{array}$ & $\begin{array}{r}1,000 \\
(0.631)\end{array}$ & $\begin{array}{c}0 \\
(0)\end{array}$ & $\begin{array}{r}162 \\
(0.147)\end{array}$ & $\begin{array}{c}7,655 \\
(0.893)\end{array}$ & 1,276 \\
\hline Pennsylvania & $\begin{array}{r}0 \\
(0)\end{array}$ & $\begin{array}{r}4,876 \\
(0.884)\end{array}$ & $\begin{array}{r}4,481 \\
(0.899)\end{array}$ & $\begin{array}{r}0 \\
(0)\end{array}$ & $\begin{array}{r}0 \\
(0)\end{array}$ & $\begin{array}{r}0 \\
(0)\end{array}$ & $\begin{array}{l}9,357 \\
(0.437)\end{array}$ & 1,560 \\
\hline Delaware & $\begin{array}{r}0 \\
(0)\end{array}$ & $\begin{array}{r}145 \\
(0.238)\end{array}$ & $\begin{array}{r}1,000 \\
(3.345)\end{array}$ & $\begin{array}{r}0 \\
(0)\end{array}$ & $\begin{array}{c}0 \\
(0)\end{array}$ & $\begin{array}{r}231 \\
(0.711)\end{array}$ & $\begin{array}{l}1,376 \\
(0.725)\end{array}$ & 229 \\
\hline Maryland & $\begin{array}{r}0 \\
(0)\end{array}$ & $\begin{array}{r}2,592 \\
(4.069)\end{array}$ & $\begin{array}{r}5,535 \\
(2.727)\end{array}$ & $\begin{array}{r}0 \\
(0)\end{array}$ & $\begin{array}{c}0 \\
(0)\end{array}$ & $\begin{array}{r}0 \\
(0)\end{array}$ & $\begin{array}{c}8,127 \\
(0.746)\end{array}$ & 1,354 \\
\hline Virginia & $\begin{array}{c}3,180 \\
\text { (infinite) }\end{array}$ & $\begin{array}{r}0 \\
(0)\end{array}$ & $\begin{array}{r}5,269 \\
(0.917)\end{array}$ & $\begin{array}{r}2,600 \\
(0.497)\end{array}$ & $\begin{array}{r}4,600 \\
(1.158)\end{array}$ & $\begin{array}{r}4,500 \\
(1.810)\end{array}$ & $\begin{array}{l}20,149 \\
(0.853)\end{array}$ & 3,358 \\
\hline North Carolina & $\begin{array}{c}2,000 \\
\text { (infinite) }\end{array}$ & $\begin{array}{r}3,000 \\
(2.646)\end{array}$ & $\begin{array}{c}0 \\
(0)\end{array}$ & $\begin{array}{r}0 \\
(0)\end{array}$ & $\begin{array}{r}3,706 \\
(3.053)\end{array}$ & $\begin{array}{c}3,000 \\
\text { (inifinte) }\end{array}$ & $\begin{array}{l}11,706 \\
(2.381)\end{array}$ & 1,951 \\
\hline South Carolina & $\begin{array}{c}4,000 \\
\text { (infinite) }\end{array}$ & $\begin{array}{r}4,000 \\
(1.933)\end{array}$ & $\begin{array}{r}350 \\
(0.212)\end{array}$ & $\begin{array}{r}2,000 \\
(1.212)\end{array}$ & $\begin{array}{r}4,500 \\
(4.951)\end{array}$ & $\begin{array}{c}6,000 \\
\text { (infinite) }\end{array}$ & $\begin{array}{l}20,850 \\
(3.321)\end{array}$ & 3,475 \\
\hline Georgia & $\begin{array}{c}1,000 \\
\text { (infinite) }\end{array}$ & $\begin{array}{r}1,950 \\
(5.556)\end{array}$ & $\begin{array}{r}750 \\
(0.527)\end{array}$ & $\begin{array}{r}3,200 \\
(4.755)\end{array}$ & $\begin{array}{r}750 \\
(8.621)\end{array}$ & $\begin{array}{r}750 \\
\text { (infinite) }\end{array}$ & $\begin{array}{r}8,400 \\
(3.315)\end{array}$ & 1,400 \\
\hline Totals & $\begin{array}{l}10,180 \\
(0.371)\end{array}$ & $\begin{array}{r}42,760 \\
(0.910)\end{array}$ & $\begin{array}{r}33,900 \\
(0.974)\end{array}$ & $\begin{array}{r}18,153 \\
(0.552)\end{array}$ & $\begin{array}{l}17,485 \\
(0.631)\end{array}$ & $\begin{array}{l}22,061 \\
(1.050)\end{array}$ & $\begin{array}{r}144,539 \\
(0.758)\end{array}$ & 24,089 \\
\hline
\end{tabular}

Source: Derived from Knox (1790); and Table 5 above.

Notes: $*=$ treats all numbers as full year enlistments, when they typically were not—often only 2 to 6 months. 
Table 9 Index of State Commitment to the Union, 1775-1784

\begin{tabular}{lcclc}
\hline & Compliance with & Continental Troops & Quota of Continental & Commitment Index: \\
& Continental Troop & versus Local & Dollars Remitted to & Un-weighted Arithmetic \\
& Quota 1777-1780 & Militia 1775-1780 & Congress by 1784 & Index (Simple Average) \\
State/Region & $\%$ & $\%$ & $\%$ & $\%$ \\
\hline
\end{tabular}

Estimated Relative Share of Congressional Spending Flows to: Moderately High

\begin{tabular}{|c|c|c|c|c|}
\hline New Hampshire & 67.1 & 64.0 & 100.0 & 77.0 \\
\hline Massachusetts & 75.8 & 70.6 & 100.0 & 82.1 \\
\hline Rhode Island & 74.9 & 44.2 & 0.0 & 39.7 \\
\hline Connecticut & 85.0 & 73.8 & 0.0 & 52.9 \\
\hline $\begin{array}{l}\text { New England } \\
\text { Sub-total }\end{array}$ & $\overline{75.7}$ & 63.2 & 50.0 & 62.9 \\
\hline
\end{tabular}

Estimated Relative Share of Congressional Spending Flows to: High

\begin{tabular}{|c|c|c|c|c|}
\hline New York & 80.3 & 54.1 & 20.0 & 51.2 \\
\hline New Jersey & 70.0 & 52.8 & 58.0 & 60.3 \\
\hline Pennsylvania & 62.6 & 69.6 & 92.0 & 74.7 \\
\hline Delaware & 58.5 & 58.1 & 100.0 & 72.2 \\
\hline $\begin{array}{l}\text { Middle States } \\
\text { Sub-total }\end{array}$ & $\overline{67.9}$ & $\overline{58.7}$ & 67.5 & 64.7 \\
\hline
\end{tabular}

Estimated Relative Share of Congressional Spending Flows to: Low

\begin{tabular}{|c|c|c|c|c|}
\hline Maryland & 58.5 & 57.3 & 0.0 & 38.6 \\
\hline Virginia & 58.9 & 54.0 & 20.0 & 44.3 \\
\hline North Carolina & 21.8 & 29.6 & 0.0 & 17.1 \\
\hline South Carolina & 30.5 & 23.1 & 0.0 & 17.9 \\
\hline Georgia & 88.8 & 23.2 & 0.0 & 37.3 \\
\hline $\begin{array}{l}\text { Southern States } \\
\text { Sub-total }\end{array}$ & $\overline{51.7}$ & $\overline{37.4}$ & 4.0 & 31.0 \\
\hline
\end{tabular}

Sources: Derived from Tables 7 and 8 above; Grubb (2008a).

Notes: See text. Column one is the number of troops provided to the Continental army as a percentage of the quota of troops requested. This quota was set roughly proportional to the state's population in the union. Column two is 
the percentage of troops provided to the Continental army as a percentage of total troops raised in the state (local militia and Continental troops). Column three is the total Continental Dollars each state taxed out of circulation and remitted to Congress as a percentage of the quota of payments requested. This quota was set roughly proportional to the state's population in the union. Column four is a simple un-weighted average of the columns one, two and three. The regional averages are simple un-weighted averages. 


\section{Footnotes}

\footnotetext{
${ }^{1}$ Maryland refused to ratify the Articles, which required unanimity, until other states had ceded their claims to vast lands west of the Appalachian Mountains to the national government.

${ }^{2}$ The unexpected cost and duration of the war led to new emissions being continually authorized before any of the prior emissions were redeemed, which in turn led to a rapid accumulation of Continental Dollars outstanding in the economy. Between the first authorization in June of 1775 and the last in November of 1779, just under \$200 million (face value) were emitted. All were still outstanding as of the beginning of 1780 as state redemptions of Continental Dollars were not required to begin until 1780. This was a lot of paper money. By 1780 it averaged $\$ 91$ per capita (of white population) face value, or the equivalent of about 20 pounds in sterling equivalents (in face value). By contrast, the money stock of the colonies before the revolution averaged around 1 pound sterling-equivalents per capita and between 1795 and 1830 the U.S. money stock averaged around 1.8 pounds sterling- equivalents per capita (Rousseau 2006). Needless to say, depreciation set in and prices rapidly inflated. By 1780 the Continental Dollar was circulating at around 40 paper dollars to 1 dollar in specie and would rapidly sink further. By mid-1781 it had ceased to circulate (Grubb 2007, 2008a, 2008b).

${ }^{3}$ See Grubb (2007) for discussions of these monetary reform efforts.

${ }^{4}$ A variant of this report is reproduced in, but not analyzed by, Carp (1984, p. 69) and Ferguson (1961, pp. 28-29). The numbers reported are clearly the same as those in the Knox (1790) report.

${ }^{5}$ See footnote 4 .
} 
${ }^{6}$ The other state and regional tables of depreciation of Continental Dollars are not price indices or even based on contemporaneous data, but were retroactively created depreciation tables to aid in financial adjustments for breach-of-contract debt cases (Grubb 2007, 2008a). 